NBER WORKING PAPER SERIES

\title{
AN INTERNATIONAL PERSPECTIVE OF JAPAN'S CORPORATE GROUPS AND THEIR PROSPECTS
}

\author{
Yishay Yafeh \\ Working Paper 9386 \\ http://www.nber.org/papers/w9386 \\ NATIONAL BUREAU OF ECONOMIC RESEARCH \\ 1050 Massachusetts Avenue \\ Cambridge, MA 02138 \\ December 2002
}

This essay was written during visits to the Saïd Business School and the Nissan Institute, University of Oxford, and to the Eitan Berglass School of Economics, Tel Aviv University, whose hospitality is gratefully acknowledged. I am extremely grateful to Masaharu Hanazaki of Hitotsubashi University and to Hideaki Miyajima of Waseda University for assistance in gaining access to Japanese data sources, to Colin Mayer for the industry growth data and to Nao Saito and Anat Tamir for research assistance. I am also grateful to the Editors of the NBER volume on Structural Impediments to Growth in Japan, and to Larry Meissner, Sumner la Croix, and participants of an NBER conference held in Tokyo for helpful comments and suggestions. The views expressed herein are those of the authors and not necessarily those of the National Bureau of Economic Research.

(C) 2002 by Yishay Yafeh. All rights reserved. Short sections of text not to exceed two paragraphs, may be quoted without explicit permission provided that full credit including, (C) notice, is given to the source. 
An International Perspective of Japan's Corporate Groups and their Prospects

Yishay Yafeh

NBER Working Paper No. 9386

December 2002

JEL No. G3, I2

\begin{abstract}
$\underline{\text { ABSTRACT }}$
This paper reviews the literature on corporate groups in Japan and elsewhere, and offers a comparison of Japan's corporate groups with groups in other developed and developing countries. It then proceeds to examine the evolution of corporate groups in Japan since the mid-1970s. The main conclusions that emerge are that: 1. Empirical evidence on the economic roles of corporate groups in Japan is limited. 2. Japanese groups are, in some respects, quite similar to groups in other countries, but their risk and return characteristics differ substantially. 3. There is little to suggest that over the past thirty years groups have had a major impact on Japan's industrial structure. In view of these findings, and because there is no evidence that Japanese groups (unlike those in some other countries) enjoy any particular political clout, it is unlikely that corporate groups will constitute an impediment to structural change in Japan.
\end{abstract}

\author{
Yishay Yafeh \\ School of Business Administration \\ The Hebrew University \\ Jerusalem 91905, Israel \\ msyafeh@pluto.mscc.huji.ac.il \\ and \\ Economics Department \\ University of Montreal \\ C.P. 6128 , Succursale \\ Centre-ville, Montral \\ H3C 3J7, CANADA \\ yishay.yafeh@umontreal.ca
}


Academic and popular views of the keiretsu, as postwar Japanese corporate groups are sometimes called, range from complete dismissal to admiration of their influence, whether it is alleged to enhance economic growth or to restrict entry into the Japanese market. During the 1990s, cross-shareholding arrangements within groups, and ties between ailing financial institutions and their client firms, have often been mentioned as potential impediments to structural change, especially with respect to the introduction of market-based means of corporate finance and governance.

The present paper has three objectives. The first is to review the literature on corporate groups in Japan and elsewhere, summarizing the evidence on the economic roles (if any) corporate groups have played in the Japanese economy. The second objective is to present, for the first time, a comparison of Japanese groups and corporate groups in other developed and developing countries. The main conclusion emerging from this comparison is that Japanese groups, while similar to groups elsewhere in some respects, are different in their risk and return characteristics. The third objective is to describe the evolution of Japan's groups since the mid-1970s and to examine whether or not groups constitute an impediment to structural change in Japan.

With some exceptions, there is limited evidence of the economic importance of corporate groups in postwar Japan. There is also little to suggest that groups have had a major impact on growth rates of particular industries, and no evidence that Japanese groups (unlike those in other countries) enjoy any particular political clout. It is therefore unlikely that corporate groups will constitute an impediment to structural change.

Powerful, family controlled, pyramidal groups (zaibatsu) existed in Japan from the late 19th century to just after World War II. Our focus here, however, is on corporate groups in postwar Japan. These are usually divided into two types. The first consist of firms operating in many industries, with large financial institutions (a city bank, a trust bank, and insurance companies) at the core. These are variously termed horizontal, financial, or bank-centered groups. There are six major groups of this type, three with zaibatsu roots.

The second type consists of a large manufacturer and related suppliers within the same industry or in closely related sectors. These are often described as vertical or manufacturer-centered groups. Examples include Toyota or Hitachi.

The discussion here focuses mostly on bank-centered groups. First I review the literature on corporate groups in general, and then evaluate the empirical evidence on the economic importance of Japan's corporate groups. I then make a cross-sectional comparison between Japanese corporate groups and those in other countries, and describe the evolution of groups in Japan over time, including their prospects. 


\section{Identifying Corporate Groups}

The criteria used to define the boundaries of a group and to identify members vary considerably across countries and studies (Khanna 2000). In most countries, including Japan, membership is typically informal. (Exceptions include Italy, where the law identifies "common control" (see Bianchi et al. 2001) and Chile, where groups are legal entities.)

Still, the literature has struggled to provide a definition - or at least definitions for each country. Leff (1978, p 673) put forward "a group of companies that does business in different markets under a common administrative or financial control," but this is clearly inappropriate in postwar Japan, where groups lack common control. Strachan (1976) defines a group as a long-term association of firms and the people who own and manage them, and points out that a group cannot be identified purely on the basis of a single metric. The criteria used to identify membership in Japanese groups have mostly been based on measures of long-term relations among member firms.

\subsection{Origins of Japanese Groups}

The prewar and war-time economy of Japan was dominated by large, diversified conglomerates (zaibatsu). At war's end the four major zaibatsu represented about a quarter of paid-in capital and a much larger shares in finance and heavy industries (Hoshi and Kashyap 2001, p 69 Box 3.5, and Hadley 1970). The zaibatsu were familyowned conglomerates, controlled through holding companies which in turn held a large number of shares in a first tier of subsidiaries. First-tier subsidiaries controlled a second tier of companies, and so forth, forming a pyramid of firms. Horizontal ownership and personnel ties between group firms were also common. ${ }^{1}$

Following Japan's defeat in 1945, the US occupation authorities (Supreme Commander for the Allied Powers $=$ SCAP) regarded the zaibatsu as an important part of the Japanese social and economic structure that was responsible for the war. In particular, the market power of the zaibatsu and the tremendous wealth of the founding families made the dissolution of the conglomerates one of the first and most important targets of the Occupation reforms.

\footnotetext{
${ }^{1}$ Okazaki (2001) argues that the zaibatsu were not powerful enough to "dominate" the Japanese economy before the start of World War II, but during the war they increased market power and played an important role in providing military equipment and supplies to the Japanese Imperial Army.
} 
The zaibatsu dissolution reforms started soon after the end of the war and ended around 1950. The holding companies were dismantled and new ones prohibited by law, the founding families were stripped of their shares, and many of the incumbent managers were purged and barred from corporate office. The resulting change of ownership was of enormous scale: some estimates suggest that over $40 \%$ of all corporate assets in Japan changed hands (Bisson 1954). The shares transferred were resold by the Holding Companies Liquidation Commission (HCLC) using several methods designed to guarantee disperse ownership structure (see Hadley 1970, p 18187). Indeed, following the conclusion of the reforms, shareholding by individuals in Japan reached an all time high of approximately 70\% around 1949 (Aoki 1988).

Despite the hopes of the Occupation, the newly created ownership structure proved unstable. With the reopening of the Tokyo Stock Exchange in 1949, individuals who received shares during the reforms (especially company employees and residents of cities where the companies operated) began to sell, and individual shareholding began to decline. By the early 1950s a new ownership structure had emerged: most companies were owned by other companies and by financial institutions, most notably large commercial banks ("city banks").

Ownership ties were sometimes part of reciprocal cross-shareholdings, often along the lines of the former zaibatsu - especially among what had been the three largest: Mitsui, Mitsubishi, and Sumitomo (see Hoshi 1994, Yafeh 1995). These ties were further reinforced in the late 1960s, and "new" groups centered on major (city) banks were formed (Dai-Ichi Bank and Nippon Kangyo Bank, which later merged to form the DKB group, Fuji, and Sanwa).

There are several possible reasons why the period of dispersed ownership was so short. Individuals may have been too poor and too risk averse to wish to hold equity, and preferred to increase their consumption or save in the form of bank accounts rather than hold shares.

Another reason asserted by many authors (for example, Miyajima 1994) is that the reformed firms were exposed to hostile takeovers once their zaibatsu shareholders were removed. Low equity prices soon after the war are posited to have made Japanese firms easy targets. In order to prevent this, managers sought to establish a friendly, stable ownership structure dominated by firms associated with each other in the prewar period. However, it is not clear who the potential raiders could have been.

An alternative explanation for the short life of extensive individual ownership is simply that it was inefficient. Yafeh (1995) shows that, other things equal, the greater the percentage of a firm's outstanding shares expropriated and resold by the Occupation, the worse was the firm's performance in the early 1950s. This is consistent with the 
view that large shareholders play an important role in corporate governance (Shleifer and Vishny 1986). Concentrated family ownership did not reappear, apparently because the "old wealth" of the prewar period had been destroyed by the reforms.

The efficiency argument is less likely to explain the reinforcement of crossshareholding in the 1960s. Then, some fear of hostile takeovers was plausible as Japan opened to foreign capital.

\subsection{Who is a Group Member?}

Unlike the prewar zaibatsu, postwar groups in Japan have no central control, and identifying affiliation with a group is not straightforward. Core members typically take part in "presidents' clubs," which are regular meetings of senior executives. Members of these clubs are easy to identify, and constitute about $10 \%$ of all listed manufacturing firms in Japan (Weinstein and Yafeh 1995).

Beyond the presidents' club, researchers have used a variety of measures to identify group members. Commonly used definitions are those of three major publications: Keizai Chosa Kyokai's Keiretsu no Kenkyu, Toyo Keizai's Kigyo Keiretsu Soran, and Dodwell Marketing Consultants' Industrial Groupings in Japan. These weigh various aspects of the relationship between a firm and other group members, most notably the extent and stability of cross-shareholding arrangements, and the extent and stability of credit and equity relations maintained with the group's main financial institutions. The frequency of personnel exchange appears to be a relatively less important component.

The existing weighting schemes (and the corresponding data sources) usually concur as far as the identification of core group members is concerned, but may differ considerably in defining the boundaries of groups. Thus, Weinstein and Yafeh (1995) find the correlation between the lists of members identified by different sources to be not very high although all commonly used definitions suggest that group affiliated companies constitute some $40 \%$ to $50 \%$ of all listed manufacturing firms. Gibson (1995), looking at bank-firm ties in the early 1990s without reference to groups, suggests that several plausible methods agree on the identity of the "main bank" of most companies, although his methodology is not designed for identifying members in bankcentered groups.

While credit relationships within groups are fairly easy to interpret, the prevalence and significance of equity ties is more controversial. The extent of equity ties reported by different sources varies within the group definition used. Mitsubishi and Sumitomo presidents' club member firms had around $25 \%$ of their equity held by other group firms in 1990, whereas the corresponding figures for other groups hover around 
$15 \%$ to $16 \%$ (Sheard 1997). Figures for non-presidents' clubs firms are typically substantially lower.

Most of the equity ties within the groups involve the group's financial institutions (banks and insurance companies). By contrast, equity ties between manufacturing firms are usually low (with equity stakes that are often less than $1 \%$ ). The meaning of these ties, which are unusually stable in spite of their small size, has been harder to interpret (see Flath 1993, Miwa and Ramseyer 2001a, and further discussion below).

The empirical literature on Japan has often treated bank-firm relations and group affiliation as one and the same. To a great extent, this is because the available definitions of group affiliation focus on ties with the group's main bank. Thus, a large number of empirical studies actually rely on group data to suggest that long term bankfirm relationships may matter for corporate governance, mitigation of informational asymmetries between the firm and its financiers, and the resolution of financial distress. (On the Japanese main bank system, see Aoki and Patrick 1994, Hoshi and Kashyap 2001, especially chapter 4).

\section{Reasons for Groups to Exist}

The literature on corporate groups has so far not reached an agreement on the most important reasons for the ubiquity of groups around the world. This section therefore begins with an evaluation of "positive" explanations for the existence of groups (viewing them as efficient solutions to various market imperfections) and their relevance to Japan. It then proceeds to discuss "negative" views of corporate groups (such as political rent-seeking and expropriation of minority shareholders) and to examine their applicability to Japan.

\subsection{Reducing Transaction Costs}

Corporate groups may be important for reducing transaction costs associated with intra-

group trade. Applying this idea to Japan, Flath (1993) argues that cross-shareholding arrangements help reduce moral hazard risks among trading partners, thus facilitating transaction-specific investments. Yet empirical evidence in support of this argument is rather scarce (Flath provides some), and it appears that the volume of intra-group trade within the bank-centered groups is rather low. Sheard (1997) estimates average intragroup sales at about $2 \%$ excluding the group's general trading company, which account for another $6+\%$. Odagiri $(1992, \mathrm{p} 182)$ reports that, in 1981 on average $20 \%$ of a group 
firm's sales and $12 \%$ of its purchases were within-group transactions.

By contrast, intra-group trade and transaction-specific investments may be a major factor explaining the structure and performance of manufacturer-centered (vertical) groups, where joint development of new products and just-in-time supply of inputs are crucial. Indeed, there is substantial evidence that manufacturer-centered groups combine insurance and incentives in a way that is designed to reduce hold-up problems through long-term relations without full vertical integration (Kawasaki and MacMillan 1987, Asanuma 1989, Fujimoto 1999).

\subsection{Coordinating Investment}

Groups may facilitate major investments by providing a mechanism for coordination across firms and industries. They may therefore be of help in orchestrating a "big push." Thus, Ohkawa and Rosovsky (1973) view the zaibatsu as an important component in prewar Japan's ability to absorb foreign technology, which could be spread across group members.

Goto (1982) argues that the reason groups are observed in a market economy like Japan is their ability to coordinate $R \& D$ and new investments. A weaker formulation of this hypothesis is that groups share information about investment opportunities, even if group members carry out investment decisions independently. Although this is not impossible, this conjecture is hard to test empirically and has never been formally examined.

Systematic evidence on joint investments and R\&D among members of Japan's postwar groups is not available. There is little in the literature on inter-firm coordination in $R \& D$ and technology absorption to suggest that the bank-centered groups have played a particularly important role in this respect (although there is some evidence on the importance of vertical groups: see Branstetter 2000, Okada 2001).

Montalvo and Yafeh (1994) find that group-affiliated firms signed more licensing agreements to import foreign technology into Japan in the late 1970s. There are several possible interpretations for this result, however. It is possible that groupaffiliated firms enjoyed easy access to capital from financial institutions within the group. It is also possible that group firms signed more licensing contracts because they were less involved in independent R\&D activity, perhaps as a result of pressure by the group's main bank to adopt low-risk investment strategies.

Using survey data from the late 1990s, Mayer, Schoors, and Yafeh (2002) note that venture capital funds in Japan often are owned by firms related to each other, as part of one of the groups or otherwise. They do not discuss the impact of this characteristic on fund performance. 


\subsection{Substituting for Missing Institutions}

Khanna and Palepu (1999) suggest groups in India and other developing countries make up for missing institutions, such as those enforcing property rights, as well as markets for skilled labor, management, and capital. This, they argue, is a plausible explanation for the evidence of superior performance of group members in India and other emerging markets, especially when groups exceed a certain size (or diversification) threshold.

This extended suggestions in the early descriptive literature that groups made up most notably for imperfect capital markets (for example, Leff 1978). Perotti and Gelfer (2001) argue that Russian financial-industrial groups (FIGs) manage an internal capital market that may add value in the face of inefficient external capital markets in that country. In addition, there is some evidence that internal capital markets in the Korean jaebol create value (Chang and Hong 2000).

Applied to skilled labor and management, the missing-institution argument could perhaps be related to the zaibatsu, which trained a generation of prewar Japanese executives, but it is more difficult to apply it to the postwar experience, and it is not supported by in any Japan-specific study.

Applied to under-developed capital markets, the missing-institution argument is undermined by the absence of evidence indicating efficient allocation of capital within the Japanese corporate groups, whose growth rates and other measures of performance have not been superior to those of non-group firms. Nevertheless, some relations between the postwar corporate groups and certain aspects of capital markets (risk sharing and corporate governance) are discussed below. In addition, Hoshi, Kashyap, and Scharsfetin $(1990,1991)$, argue that investment decisions of group affiliated companies are less sensitive to their cash flow positions than investment decisions of non-group firms, and also that some unnecessary bankruptcies are prevented within the groups. This could be viewed as evidence that groups do make up for some deficiencies of imperfect capital markets in the allocation of capital.

\subsection{Providing Mutual Insurance}

One function of capital markets that has been associated with corporate groups is the provision of mutual insurance opportunities for member firms. This idea originates in the literature on Japanese groups, where several studies suggest that groups provide an organizational mechanism through which risks are shared. A theoretical formulation of this hypothesis by Aoki (1988) suggests that employees with firm-specific human capital cannot easily protect themselves against adverse shocks and therefore appreciate risk reduction through firm relations with other firms within a corporate group, and 
especially with the group's main bank.

Nakatani (1984) provides empirical support for the claim that Japanese corporate groups provide a low-profit and low-volatility environment. Kashyap (1989) suggests that the low volatility of profits documented by Nakatani is a result of intra-group trade relations (and therefore is not a characteristic of final-good producers within the groups).

There is evidence on a particular form of risk sharing under the auspices of the main bank within the big-six groups, namely, assistance during financial distress. For example, Sheard (1989) documents a variety of cases in which banks rescued ailing clients, typically within their group and often with the assistance of other group members. Hoshi and Kashyap (2001, chapter 5) discuss bank interventions.

Weinstein and Yafeh (1998) argue that members of bank-centered Japanese groups adopt low-risk investment strategies, although the motivation for this behavior is, in their view, related not to risk sharing but to the (excessive) influence that the group bank and other creditors exert on group firms. Khanna and Yafeh (2001) conduct a battery of risk-sharing tests among corporate groups in Japan and elsewhere, and find consistent evidence for mutual insurance among member firms of Japanese (and Korean) corporate groups, in contrast with most of the other countries they examine.

Thus, while there is limited evidence on other possible economic roles of corporate groups in Japan, the risk-sharing hypothesis does enjoy some empirical support. Further, this mutual insurance feature seems to distinguish Japanese groups from most corporate groups in emerging markets. The sociological literature has also emphasized risk sharing within Japan's corporate groups (for example, Lincoln et al 1996). But, the evidence on risk sharing within corporate groups in Japan has not been unchallenged (see Beason 1998, Kang and Stulz 2000, and Miwa and Ramseyer 2001a, 2001b). Further discussion on risk and return within groups is included below.

\subsection{Corporate Governance}

Another capital market function that has sometimes been associated with Japanese corporate groups is corporate governance. For example, group members are viewed as important in the theoretical corporate governance model of Berglof and Perotti (1994). Yet, overall, empirical support for the special role of groups in corporate governance appears to be limited. There is much evidence on the role of main banks, typically within corporate groups, in disciplining managers of distressed firms, and in restructuring their operations (Yafeh 2000, Hoshi and Kashyap 2001). There is also some evidence on the role of large shareholders (often part of the group) in corporate governance, again mostly with respect to poorly performing companies (Kang and 
Shivdasani 1995, 1997). Yafeh and Yosha (2002) provide some evidence for the role of large shareholders in corporate governance in companies whose performance is normal. There is very little to suggest that corporate groups contribute to corporate governance beyond the roles played by the group banks and by large shareholders (although it is perhaps possible to argue that the group provides a framework in which main banks and large shareholders operate).

\subsection{Monopoly Power}

The fear that groups with "deep pockets" may drive more focused (smaller) competitors out of the market is not new, and was one of the motivations for the American occupation authorities' drive to dissolve the zaibatsu (Yafeh 1995). While groups in some countries (for example, Korea) do appear to dominate markets, the general evidence on the relation between market power and corporate groups is weak. Encaoua and Jacquemin (1982) find little evidence of monopolization by French groups. Lawrence (1993) argues that Japanese groups constitute a barrier to entry because they prefer to purchase inputs from other group members, and thus restrict competition by foreign firms. The evidence on the limited extent of intra-group trade is inconsistent with this argument and, moreover, Lawrence's empirical evidence in support of this argument is not fully convincing (Saxonhouse 1993).

Weinstein and Yafeh (1995) use an industrial organization framework to examine the relation between the intensity of competition and the market share of Japanese bank-centered groups. They suggest that, if anything, group members tend to compete more aggressively than other firms; although fierce competition may well constitute a barrier to entry, there is no evidence of collusion among group members at the expense of "outsiders."

\subsection{Political Rent Seeking}

As in prewar Japan, the origins of corporate groups and their initial growth in many countries were influenced by close ties with the government. The zaibatsu emerged in the $1880 \mathrm{~s}$ as part of the Matsukata privatization of government-owned assets and expanded to a large extent through government contracts and procurement. Groups in India emerged after independence when businessman with government ties acquired assets that had belonged to the British. In Korea the jaebol were formed under the auspices of the government and started off by using assets left at the end of the Japanese colonial period. Such close government ties have prompted accusations that corporate groups derive benefits from rent seeking and government favors, and are therefore inefficient. Fisman (2001) finds explicit evidence for this in Indonesia. 
There are no studies linking postwar Japanese groups with corruption or specific government favors and contracts. Industrial policy was notoriously conducted at the industry level and no firm-specific subsidies were given (Johnson 1982). Corruption scandals have not involved group-affiliated firms more than other corporations, and corporate groups have never been mentioned as part of any political party's constituency. (For the ruling LDP, these traditionally are thought of as being farmers, small shop owners, and perhaps the construction industry).

One measure of government-business ties in Japan is the practice of amakudari, the transfer of bureaucrats from the government to the private sector. van Rixtel (2002) finds that firms within corporate groups are less likely to receive amakudari than other firms.

\subsection{Expropriation of Minority Shareholders}

A growing literature has blamed corporate groups with the expropriation of minority shareholders. Claessens et al. (1999) argue that groups are associated with minority shareholder expropriation in Asia. Similarly, Johnson et al. (2000), as well as Bertrand et al. (2002) view groups as institutions that are associated with poor protection of property rights and enable "tunneling" of funds from minority shareholder to the controlling party. This argument is unlikely to be particularly relevant to Japan, most notably because Japanese groups do not have a controlling shareholder, and also because, according to the commonly used La Porta et al. (1998) classification, the legal protection of minority shareholders in Japan is, by international standards, not bad. Even though some cases in which unhappy Japanese shareholders sued corrupt corporations have been reported in the press, there is little systematic evidence to suggest that group-affiliated firms in Japan be particularly prone to minority shareholder expropriation. $^{2}$

\subsection{Summary}

Much has been written on Japan's corporate groups, and yet concrete evidence (positive or negative) on their economic importance is surprisingly scarce. Only the groups' role in mutual risk sharing has received some empirical support. In addition, there is much evidence that large shareholders (often within a corporate group), and main bank

\footnotetext{
2 Ando, Christelis, and Miyagawa (2002) observe that Japanese shareholders are in a weak position relative to management, which, they argue, has been able to pursue non-profit maximization objectives. The concern here is in the spirit of the "tunneling" literature (Johnson et al. 2000), focusing on how insider, usually majority, shareholders treat other shareholders, especially within corporate groups. According to the standard measures of statutory legal protection used in the recent finance literature, Japanese minority shareholders enjoy many of the legal protection measures of common law countries.
} 
relationships (also typically within a corporate group) are often important for corporate governance, although there is little to suggest the importance of the group structure per se. It is therefore possible to conclude that the limited evidence on Japan's corporate groups is (weakly) consistent with the positive views of corporate groups as substitutes for missing (capital market and other) institutions.

\section{Comparing Groups in Japan and Elsewhere}

This section compares Japan's corporate groups with groups in other countries. They, of course, may differ substantially in structure and mode of operation but, at the same time, have many common features (most notably cross shareholding). The main thrust of the comparison is that Japanese groups are not unique in structure, but are perhaps "special" in their (low) risk and (low) return characteristics. Because of data constraints, and perhaps also because groups are less common in developed economies, most of the countries included in this comparison are "emerging markets," although some comparisons will be made with Italian groups.

\subsection{A First Look}

Table 1 describes corporate groups in Japan and in a several emerging markets. The fraction of firms classified as group affiliated ranges from about a fifth in Chile and Venezuela to about two-thirds in Indonesia. In Italy more than half of all industrial companies belong to pyramidal groups (Bianchi et al. 2001). In Japan, members of presidents' clubs account for fewer than $10 \%$ of listed manufacturing firms, whereas other group definitions (for example, those of Dodwell Marketing Consultants and Keiretsu no Kenyu) identify close to a half of all listed manufacturing firms as members. Thus, in terms of overall prevalence groups, Japan does not seem to be different.

Table 1 also indicates that in Japan, as well as in virtually all the other countries for which data are available (Turkey being the only exception), group affiliated firms are larger than unaffiliated firms. Difference in median size between presidents' clubs members and other firms are somewhat bigger than differences in means - the mean size of presidents' clubs members is about seven times that of non-members. The mean size of firms that are classified as group affiliated by Dodwell is about $50 \%$ larger than the size of unaffiliated firms.

This pattern is very pronounced in Italy as well, where large firms are predominantly group affiliated: over $99 \%$ of firms with over 1000 employees are group members, as are about $89 \%$ of the firms with $500-1000$ employees. By contrast, less 
than $40 \%$ of small firms (fewer than 100 employees) are group members (Bianchi et al. 2001).

\subsection{Group Organization and Location across Industries}

Japan's postwar corporate groups are different from groups in many other countries in the conspicuous absence of a centralized decision-making mechanism. Without holding companies (legally banned between the end of World War II and 1998) or other formal joint control mechanism, it is hard to expect groups to coordinate their activities very extensively. This is in sharp contrast with Italian groups, where an elaborate pyramid structure guarantees centralized control; indeed, Bianchi et al. (2001) argue that the very reason for the prevalence of groups in Italy is to generate a wedge between control and cash flow rights.

Although the degree of cohesiveness of groups varies across countries and across groups, in many emerging markets, including Korea, groups seem to be far more centrally controlled than they are in Japan. Thus, the "loose" structure of Japan's postwar groups appears to be distinctly different than the structure of groups in many emerging markets (and also in sharp contrast with the prewar period).

The spread of groups across manufacturing industries is displayed in Table 2. (There are insufficient data to include services). Perhaps the most notable pattern is the absence of a clear pattern of group location across industries, although there is some evidence that groups in several countries tend to locate in somewhat more capitalintensive industries. This pattern is reminiscent of the zaibatsu in prewar Japan, although it is far from universally true.

Postwar Japanese group firms seem to be evenly spread across many sectors (the so called "one-set policy"). This pattern is not unique to Japan; for example Chilean groups also seem to exhibit this tendency, although their structure appears to be less "complete" than that of the Japanese groups. In terms of sales, relatively more capitalintensive sectors such as metals and chemicals seem to be particularly important for Japan's corporate groups in terms of both the fraction of total group assets and group firms' market shares. These sectors are generally important for the Japanese economy as a whole, so this finding is hardly surprising.

The importance of services, most notably financial services, varies tremendously among groups in different countries. Whereas in some countries groups' entry into the financial services industry has been restricted (for example, Korea), in other countries services constitute the bulk of group activity. Thus, it appears that, aside from the loose control, the structure and organization of Japan's corporate groups is not unique. 


\subsection{Risk and Return}

Table 3 displays simple profit rates and profit volatility statistics for group and nongroup member firms in Japan and elsewhere. In 6 of 12 countries in the table, profit rates and profit volatility are lower for group affiliated firms, though not always in a statistically significant manner.

Japanese corporate groups are among those characterized by low risk and low profitability, although differences in medians appear to be small and not statistically significant. Differences in mean profitability (3.7\% for members of presidents' clubs versus $4.0 \%$ for other firms) are also statistically insignificant, although differences in mean standard deviation of profitability are statistically significant (standard deviation of operating profitability of 2.4 for Presidents' Clubs members versus 2.9 for other firms). Using the Dodwell definition, group firms exhibit significantly lower mean profitability, as well as significantly lower mean and median standard deviation of profitability relative to other firms.

The characterization of the Japanese groups as providing a low-risk and lowreturn environment is borne out in more sophisticated econometric tests of the mutual insurance hypothesis conducted in Khanna and Yafeh (2001). They report that Japanese corporate groups (members of presidents' clubs) seem to provide mutual insurance for members firms according to five of the six tests they conducted. ${ }^{3}$

This is hardly true for most groups around the world: although groups in Korea and a few other countries also seem to provide a low-risk environment according to these tests, groups in most emerging markets do not. Further, there seems to be little relation between the extent of development of a country's financial system and the extent of mutual insurance provided by groups. In Japan too, there is little difference

3 There are six tests. 1) A benchmark OLS regression where the standard deviation of operating profitability is regressed on a number of control variables and a group affiliation dummy. 2) A test of the relation between the squared residuals from a regression with profitability as a dependent variable, and a group affiliation dummy. 3) Tests of first order stochastic dominance comparing the distributions of profit volatility among group affiliated and non-affiliated firms. 4) A test comparing whether the distribution of profitability among group firms is more skew than among non-group firms because groups bail out member firms in financial distress and should therefore include fewer poorly performing members. 5) A test derived from Asdrubali, Sorensen and Yosha (1996) of the extent to which shocks to profitability are smoothed through changes in dividends received. 6) A two-dimensional stochastic dominance test of the hypothesis that group affiliated firms exhibit both low profitability and low profit volatility relative to non-group firms. For Japanese groups, evidence of risk sharing (low profit volatility) was found in all of the tests except the last. 
between measures of mutual insurance within corporate groups before and after the liberalization of Japan's financial markets in the 1980s.

The simple profitability statistics reported in Table 3 suggest that in many cases group-affiliated firms outperform their unaffiliated counterparts. More detailed econometric studies (controlling for various firm and group characteristics) also confirm that group membership is often associated with superior performance. (See Chang and Choi 1988 for Korea; Keister 1998 for China; Khanna and Palepu 1999 and 2000 for Chile and India.)

By contrast, the raw figures for Japan, suggesting lower profit rates for group affiliated firms, are confirmed by a long list of empirical studies. Caves and Uekusa (1976), Nakatani (1984), Odagiri (1992), Weinstein and Yafeh (1995, 1998), and Kang and Shivdasani (1999) all find that members of bank-centered Japanese groups underperform otherwise comparable unaffiliated firms. Weinstein and Yafeh (1998) also point out that growth rates among group affiliated companies were never higher than growth rates of corresponding unaffiliated companies.

A plausible explanation for this phenomenon is that Japanese group firms do something other than profit maximization, perhaps in accordance with the interests of influential creditors (banks) within the group. We conclude that, in terms of risk and return trade-offs, Japanese corporate groups appear to differ from most of the corporate groups elsewhere.

For further discussion of the reasons for low profit rates among group firms see Hoshi and Kashyap (2001, p 200-03). Okazaki (2001) finds that in the prewar period firms affiliated with zaibatsu exhibited higher profit rates than comparable unaffiliated firms, in contrast to the postwar period.

\section{Long-term Changes and Prospects}

This section begins with an evaluation of the impact of corporate groups on the development of the Japanese economy in the long run. It then proceeds to a discussion of the evolution of the groups over time, continues to discuss the relative performance

of group members in the 1990s, and concludes with an examination of the weakening of cross-shareholding and banking ties.

\subsection{Long-Run Development of Industries}

One (admittedly rough) way to evaluate the impact of corporate groups on the development of industries is to compare the growth rates of industries in Japan and the 
United States, and to relate the differences to group presence. Using industry-level growth rates (drawn from Carlin and Mayer 1999), Table 4 displays the fastest growing and declining industries in the United States and Japan for the period 1970-95.

In terms of capital formation, the same industries lead the list in both countries; in terms of growth of value added, there are some differences. Declining industries in the two countries also are quite similar. For the purpose of the present discussion, there is nothing to suggest that the growth rates of Japanese industries where group presence is more pronounced are substantially different than in the United States. Note that it is difficult to calculate the correlation between industry growth and group market share because the industry definitions Carlin and Mayer used are somewhat different than the 2-digit SIC used in Table 2.

\subsection{Industry Location}

Group affiliation data drawn from the 1994 Keiretsu no Kenkyu suggest that group members were spread across many sectors, with their presence more pronounced in the chemicals, machinery, and electronics industries, much as in earlier periods. The differences in size between group and non-group firms documented earlier seem to have persisted into the 1990s, and, much as in earlier periods, group firms are still somewhat more leveraged (Table 5). There is no reason to believe groups have re-organized so as to focus more on certain industries, and there is little evidence that the structure of Japan's corporate groups has changed significantly in other ways, at least until the mid 1990s.

\subsection{Performance in the 1990 s}

Table 5 suggests that small differences in ROA are still present in the 1990s, with group-affiliated companies being somewhat less profitable than unaffiliated firms. The table also suggests that the characterization of group members as less volatile appears to hold for the 1990s as well.

Differences in profitability between group members and unaffiliated firms are clearly observed in the multivariate regressions displayed in Table 6. It is also interesting to note that while the average group-affiliated company experienced (nominal) asset growth of about 10\% between 1991 and 2000, the assets of non-group companies grew, on average, at about $17 \%$ during the same period. Thus, risk and return differences between group members and other companies seem to hold in the 1990s as well.

To the extent that performance differences in earlier years were due to bank monopoly power, leading to non-profit-maximization among group firms (see Weinstein 
and Yafeh 1998), the evidence from the 1990s may attest to continued influence of banks on remaining clients, despite on-going liberalization. Low profitability of group members as a result of low risk strategies may still explain some of the differences in the 1990s, as the low volatility of profits suggests. The banking crisis may have had a negative effect on firms with ties to ailing banks and is another possible explanation for these findings (see Kang and Stulz 2000). Finally, it is quite possible that some of the relatively poor performance of group members in the 1990s is due to the phenomenon of good firms ending their long-term ties with their main bank, and possibly with their bank-centered group (see Hoshi and Kashyap 2001, p 241-48, and further discussion below).

\subsection{Cross-Shareholding}

The on-going recession in Japan and the decline in share prices may have made crossshareholding arrangements costly to maintain and the weakness of the group's main banks may have also contributed to the disintegration of the groups. At the same time, it is possible to argue that mutual risk-sharing arrangements within the groups are particularly valuable in the present economic conditions.

Suzuki (1998) reports that the sale of equity stakes held by corporations for long periods of time had not been a widespread phenomenon at the time he conducted his research. However, Okabe (2001) shows that substantial divestment of shares has been going on within the corporate groups since the late 1990s, especially by non-financial corporations. His main finding is that non-financial corporations have reduced crossshareholding ties with financial institutions substantially, whereas other forms of cross shareholding within groups (among financial institutions, between financial institutions and non-financial corporations, and among non-financial corporations) have remained virtually unchanged. For example, shares held by financial institutions as part of crossshareholding arrangements remained roughly unchanged between 1987 and 1997, and then declined from about $8 \%$ of all shares to $6 \%$ in 1999 . This reflects a decrease of similar magnitude in shareholding by financial institutions in both financial and nonfinancial companies. By contrast, shareholding by non-financial corporations declined somewhat in the early 1990s and then, during 1995-99, declined from about $9 \%$ of total market value to $4.5 \%$. This is accounted for primarily by a 4.1 percentage-point fall in shares held by corporations in financial institutions (Okabe 2001, Table 2). A Nippon Life Insurance (2001) study, which is the source of Okabe's figures, confirms more broadly that the reduction in cross shareholding is a phenomenon of the second half of the 1990s, and that it is common to all major corporate groups. Some data are in Table 7. 
In spite of these trends, comparisons of membership in presidents' clubs show little evidence of group disintegration between 1989 and 1999. It is important to note also that these figures are somewhat sensitive to the definition of group affiliation and cross- or stable shareholding ties.

\subsection{Banking Ties and Mergers}

The trend of decreasing cross shareholding ratios, especially between non-financial corporations and banks, is likely to be exacerbated by firms deciding to discontinue their long-term relations with the group's main banks. There is now no doubt that this phenomenon, which was documented initially by Hoshi, Kashyap, and Scharfstein (1993), and more recently in Anderson and Makhija (1999) and in Miyajima and Arikawa (2001), is of large magnitude.

The merger wave among financial institutions that cuts across traditional group lines is another factor that is likely to destabilize the existing group structure. For example, mergers between DKB and Fuji banks (together with the Industrial Bank of Japan), and between Sakura (Mitsui) and Sumitomo banks, could potentially lead to mergers of their clients firms. An early 2002 example of this is the merger talks between the marine and fire insurance companies of the Mitsui and Sumitomo groups. Mitsui Chemical and Sumitomo Chemical merged in 1998, and NKK, part of the Fuji group, formed a strategic alliance with Kawasaki Steel of the DKB group. It will certainly alter the previous situation in which no group contains two competing firms, and no bank serves as main bank to competing companies.

\subsection{Summary}

It is clear that Japan's corporate groups have been changing, and that the bank-firm (equity and debt) ties which were at their core, have been substantially weakened. One telling indicator of a declining importance of groups is the cessation of publication of two main data sources on groups (Keiretsu no Kenkyu ceased publication in 1998 and Kigyo Keiretsu Soran in 2000). This decline in corporate groups appears to be associated with a general move towards a more market-based financial system in Japan (Hoshi and Kashyap 1999) and may even have contributed to the decline in Japanese stock prices. Yet it would be ridiculous to argue that the miserable stock returns are simply due to dumping of shares formerly held within corporate groups. The unwinding of cross shareholdings should contribute to market liquidity, although this effect is hard to assess given the deteriorating macroeconomic conditions.

A decrease in stable shareholding within corporate groups is likely to increase the likelihood of hostile takeovers. Indeed, a few takeovers were observed in Japan in 
the late 1990s (Yafeh 2000), but none involved a core group company.

\section{Conclusion}

Corporate groups in Japan are undergoing significant change reflected in declining cross shareholding, as well as in weakened main bank relationships. The consolidation of banks across groups is likely to accelerate this trend, making former main bank relationships obsolete. If groups were ever an impediment to structural change, perhaps most notably as hindrances to hostile takeovers and market-based corporate governance, they are unlikely to constitute a major obstacle in the future. ${ }^{4}$

For all the attention Japanese groups attracted in the last third of the 20th century, not much is going to be missed from their demise, at least in terms of the economic roles they played. Even the mutual insurance provided within corporate groups is likely to decline in importance, as firm-specific human capital will lose some of its value and financial markets become ever more developed.

Similarly, the corporate governance roles allegedly played by large shareholders and financial institutions within the corporate groups are likely to be replaced by new, perhaps more market-oriented mechanisms, guaranteeing the efficient operations of firms. Thus, limited economic importance, combined with little political clout, suggest that Japan's corporate groups are unlikely to constitute an impediment to future changes in financial markets and corporate strategy.

Despite the large literature on corporate groups in Japan and elsewhere, the phenomenon of business groups still has many unanswered questions. Why is it that groups are observed in so many countries in early stages of their economic development? What is the most important reason for their existence? Why is the mutual insurance function of groups more important in Japan and a few other countries than in most emerging markets? How do groups evolve over time, and does their development pattern provide any evidence on their raison d'être? Will the Japanese groups provide the first example of groups that end their lives peacefully, or will government intervention be needed? These are only some of the questions on corporate groups that await further research.

\footnotetext{
${ }^{4}$ Peek and Rosengren (2002) express a different view, arguing that loans by financial institutions within groups impede "creative destruction" by prolonging the life of weak corporate borrowers. Although longterm bank-firm relations may prevent some bankruptcies of firms that are no longer viable, it is not clear that corporate groups substantially exacerbate this tendency.
} 


\section{References}

Anderson, Christopher and Anil Makhija (1999), "Deregulation, Disintermediation, and Agency Costs of Debt: Evidence from Japan," Journal of Financial Economics, 51: 309-39.

Ando, Albert, Dimitrios Christelis, and Tsutomu Miyagawa (2002) "Inefficiency of Corporate Investment and Distortion of Savings Behavior," in Magnus Blomström, Jennifer Corbett, Fumio Hayashi, and Anil Kashyap (eds.), Structural Impediments to Growth in Japan, forthcoming (Chicago, University of Chicago Press).

Aoki, Masahiko (1988), Information, Incentives and Bargaining in the Japanese Economy (Cambridge, Cambridge University Press).

Aoki, Masahiko and Hugh Patrick (eds.) (1994), The Japanese Main Bank System: Its Relevance for Developing and Transforming Economies (Oxford, Oxford University Press).

Asdrubali, Pierfederico, Bent Sorensen, and Oved Yosha (1996), "Channels of Interstate Risk Sharing: United States, 1963-1990," Quarterly Journal of Economics, 111: 1081-10.

Asanuma, Banri (1989), "Manufacturer-Supplier Relationships in Japan and the Concept of a Relation-Specific Skill," Journal of the Japanese and International Economies, 3: 1-30.

Beason, Richard (1998), "Keiretsu Affiliation and Share Price Volatility in Japan," Pacific Basin Finance Journal, 6: 27-43

Berglof, Erik and Enrico Perotti (1994), "The Governance Structure of the Japanese Financial Keiretsu," Journal of Financial Economics, 36: 259-84.

Bertrand, Marianne, Paras Mehta, and Sendhil Mullainathan (2002) "Ferreting Out Tunneling," Quarterly Journal of Economics, 117: 121-48.

Bianchi, Marcello, Magda Bianco, and Luca Enriques (2001), “Ownership, Pyramidal Groups, and the Separation between Ownership and Control in Italy," in Fabrizio Barca and Marco Becht (eds.), The Control of Corporate Europe (Oxford, Oxford University Press).

Bisson, Thomas (1954), Zaibatsu Dissolution in Japan (Berkeley CA, University of California Press).

Branstetter, Lee (2000), "Vertical Keiretsu and Knowledge Spillovers in Japanese Manufacturing: An Empirical Assessment," Journal of the Japanese and International Economies, 14: 73-104.

Carlin, Wendi and Colin Mayer (1999), "Finance, Investment, and Growth," CEPR Discussion Paper 2223, forthcoming, Journal of Financial Economics. 
Caves, Richard and Masu Uekusa (1976), Industrial Organization in Japan (Washington DC, The Brookings Institution).

Chang, Sea-jin and Unghwan Choi (1988), "Strategy, Structure, and Performance of Korean Business Groups: A Transaction Cost Approach," Journal of Industrial Economics, 37: 141-58.

Chang, Sea-jin. and Jaebum Hong (2000), "The Economic Performance of the Group Affiliated Companies in Korea: Groupwise Resource Sharing and Internal Transactions," Academy of Management Journal, 43: 429-48.

Claessens, Stijn, Simon Djankov, Joseph Fan, and Larry Lang (1999), "The Rationale for Groups: Evidence from East Asia," unpublished manuscript, The World Bank.

Encaoua, David and Alexis Jacquemin (1982), "Organizational Efficiency and Monopoly Power: The Case of French Industrial Groups," European Economic Review, 19: 25-51.

Fisman, Raymond (2001), "Estimating the Value of Political Connections," American Economic Review, 91: 1095-102.

Flath, David (1993), "Shareholding in the Keiretsu: Japan's Corporate Groups," Review of Economics and Statistics, 75: 249-57.

Fujimoto, Takahiro (1999), The Evolution of a Manufacturing System at Toyota (Oxford, Oxford University Press).

Gibson, Michael (1995), "Can Bank Health Affect Investment? Evidence from Japan," Journal of Business, 68: 281-308.

Goto, Akira (1982), "Business Groups in a Market Economy," European Economic Review, 19: 53-70.

Hadley, Eleanor (1970), Antitrust in Japan (Princeton NJ, Princeton University Press).

Hoshi, Takeo (1994), "Evolution of the Main Bank System in Japan," in Mitsuaki Okabe (ed.), The Structure of the Japanese Economy (London, Macmillan).

Hoshi, Takeo and Anil Kashyap (2001), Corporate Financing and Governance in Japan: The Road to the Future (Cambridge MA, MIT Press).

Hoshi, Takeo, Anil Kashyap, and David Scharfstein (1990), "The Role of Banks in Reducing the Costs of Financial Distress in Japan," Journal of Financial Economics, 27: 67-88.

Hoshi, Takeo, Anil Kashyap, and David Scharfstein (1991), "Corporate Structure, Liquidity and Investment: Evidence from Japanese Industrial Groups," Quarterly Journal of Economics, 106: 33-60.

Hoshi, Takeo, Anil Kashyap, and David Scharfstein (1993), "The Choice between Public and Private Debt: An Analysis of Post Deregulation Corporate Financing 
in Japan,” NBER Working Paper 4421.

Johnson, Chalmers. (1982), MITI and the Japanese Miracle: The Growth of Industrial Policy, 1925-1975 (Stanford CA, Stanford University Press).

Johnson, Simon, Peter Boone, Alasdair Breach, and Eric Friedman (2000), "Corporate Governance in the Asian Financial Crisis," Journal of Financial Economics, 58: 141-86.

Kang, Jun-Koo and Anil Shivdasani (1995), "Firm Performance, Corporate Governance, and Top Executive Turnover in Japan," Journal of Financial Economics, 38: 2958.

Kang, Jun-Koo and Anil Shivdasani (1997), "Corporate Restructuring During Performance Declines in Japan,” Journal of Financial Economics, 46: 29-65.

Kang, Jun-Koo and Anil Shivdasani (1999), "Alternative Mechanisms of Corporate Governance in Japan: An Analysis of Independent and Bank-Affiliated Firms," Pacific Basin Finance Journal, 7: 1-22.

Kang, Jun-Koo and Ren Stulz (2000), “Do Banking Shocks Affect Firm Performance? An Analysis of the Japanese Experience," Journal of Business, 73: 1-23.

Kashyap, Anil (1989), "Empirical Evidence on the Insurance Aspects of Japanese Industrial Alliances," unpublished $\mathrm{PhD}$ dissertation, MIT.

Kawasaki, Seiichi and John McMillan (1987), "The Design of Contracts: Evidence from Japanese Subcontracting," Journal of the Japanese and International Economies, 1: 327-49.

Keister, Lisa (1998), "Engineering Growth: Business Group Structure and Firm Performance in China's Transition Economy," American Journal of Sociology, 10: 404-40.

Khanna, Tarun (2000), "Business Groups and Social Welfare in Emerging Markets: Existing Evidence and Unanswered Questions," European Economic Review, 44: 748-61.

Khanna, Tarun and Krishna Palepu (1999), "Policy Shocks, Market Intermediaries, and Corporate Strategy: The Evolution of Business Groups in Chile and India," Journal of Economics and Management Strategy, 8: 271-310.

Khanna, Tarun and Krishna Palepu (2000), "Is Group Membership Profitable in Emerging Markets? An Analysis of Diversified Indian Business Groups," Journal of Finance, 55: 867-91.

Khanna, Tarun and Yishay Yafeh (2001), "Business Groups and Risk Sharing around the World," unpublished manuscript, Harvard Business School.

La Porta, Rafael, Florencio Lopez de Silanes, Andrei Shleifer and Robert Vishny (1998), "Law and Finance," Journal of Political Economy, 106: 1113-55. 
Lawrence, Robert (1993), “Japan's Different Trade Regime: An Analysis with Particular Reference to Keiretsu," Journal of Economic Perspectives, 7: 3-19.

Leff, Nathaniel (1978), "Industrial Organization and Entrepreneurship in the Developing Countries: The Economic Groups," Economic Development and Cultural Change, 26: 661-75.

Lincoln, James, Michael Gerlach, and Christina Ahmadjian (1996), "Keiretsu Networks and Corporate Performance in Japan," American Sociological Review, 61: 67-88.

Mayer, Colin, Koen Schoors, and Yishay Yafeh (2002), "Sources of Funds and Investment Strategies of Venture Capital Funds: Evidence from Germany, Israel, Japan and the UK," CEPR Discussion Paper 3340.

Miwa, Yoshiro and Mark Ramseyer (2001a), "The Fable of the Keiretsu," Harvard Law School Discussion Paper 316.

Miwa, Yoshiro and Mark Ramseyer (2001b), "The Myth of the Main Bank: Japan and Comparative Corporate Governance," University of Tokyo CIRJE Discussion Paper F-131.

Miyajima, Hideaki (1994), "The Transformation of Zaibatsu to Postwar Corporate Groups-From Hierarchically Integrated Groups to Horizontally Integrated Groups," Journal of the Japanese and International Economies, 8: 293-328.

Miyajima, Hideaki, and Yasuhiro Arikawa (2001), "Relationship Banking and Debt Choice: Evidence from the Liberalization in Japan,” Waseda University Institute of Financial Studies Working Paper.

Montalvo, Jose and Yishay Yafeh (1994), "A Micro-econometric Analysis of Technology Transfer: The Case of Licensing Agreements of Japanese Firms," International Journal of Industrial Organization, 12: 227-44.

Nakatani, Iwao (1984), “The Economic Role of Financial Corporate Grouping," in Masahiko Aoki (ed.), The Economic Analysis of the Japanese Firm (New York NY, North Holland).

Nippon Life Insurance (2001), "The Year 2000 Survey on the State of Cross Shareholding" (in Japanese), available at http://www.nli-research.co.jp

Odagiri, Hiroyuki (1992), Growth through Competition, Competition through Growth (Oxford, Oxford University Press).

Ohkawa, Kazushi and Henry Rosovsky (1973), Japanese Economic Growth: Trend Acceleration in the Twentieth Century (Stanford CA, Stanford University Press).

Okabe, Mitsuaki (2001), "Are Cross Shareholdings of Japanese Corporations Dissolving? Evolution and Implications," University of Oxford, Nissan Institute Occasional Paper 33.

Okada, Yoshitaka (2001), “Cooperative Learning and Japan's Techno-Governance 
Structure: Exploratory Case Studies," Sophia International Review, 23(1): 1942.

Okazaki, Tetsuji (2001), "The Role of Holding Companies in Prewar Japanese Economic Development: Rethinking Zaibatsu in Perspective of Corporate Governance,” Social Science Japan, 4: 243-68.

Peek, Joe and Eric Rosengren (2002), "Corporate Affiliation and the (Mis) Allocation of Credit," paper presented at the NBER Strategic Alliances conference.

Perotti, Enrico and Stanislav Gelfer (2001), "Red Barons or Robber Barons? Governance and Financing in Russian Financial-Industrial Groups," European Economic Review, 45: 1601-17.

Saxonhouse, Gary (1993), "What Does Japanese Trade Structure Tell Us about Japanese Trade Policy?" Journal of Economic Perspectives, 7: 21-43.

Sheard, Paul (1989), "The Main Bank System and Corporate Monitoring and Control in Japan," Journal of Economic Behavior and Organization, 11: 399-422.

Sheard, Paul (1997), "Keiretsu, Competition and Market Access," in Edward Graham and David Richardson (eds.), Global Economic Policy (Washington DC, Institute of International Economics).

Shleifer, Andrei and Robert Vishny (1986), "Large Shareholders and Corporate Control," Journal of Political Economy, 94: 461-88.

Strachan, Harry (1976), Family and Other Business Groups in Economic Development: The Case of Nicaragua (New York NY, Praeger Press).

Suzuki, Kazunori (1998), "Inter-Corporate Shareholding in Japan: Their Significance and Impact of Sales of Stakes," unpublished manuscript, London Business School.

van Rixtel, Adrian (2002), Informality and Monetary Policy in Japan: The Political Economy of Bank Performance (Cambridge, Cambridge University Press).

Weinstein, David and Yishay Yafeh (1995), "Collusive or Competitive? An Empirical Investigation of Keiretsu Behavior," Journal of Industrial Economics, 43: 35976.

Weinstein, David and Yishay Yafeh (1998), "On the Costs of a Bank-Centered Financial System: Evidence from the Changing Main Bank Relations in Japan," Journal of Finance, 53: 635-72.

Yafeh, Yishay (1995), "Corporate Ownership, Profitability, and Bank-Firm Ties: Evidence from the American Occupation Reforms in Japan," Journal of the Japanese and International Economies, 9: 154-73.

Yafeh, Yishay (2000), “Corporate Governance in Japan: Past Performance and Future Prospects," Oxford Review of Economic Policy, 16: 74-84. 
Yafeh, Yishay and Oved Yosha (2002), "Large Shareholders and Banks: Who Monitors and How," Economic Journal, (forthcoming) 
Table 1

Corporate Groups: Japan and Emerging Markets

\begin{tabular}{ccl}
\hline $\begin{array}{c}\text { Percent } \\
\text { in group }\end{array}$ & $\begin{array}{c}\text { Relative } \\
\text { Size }^{2}\end{array}$ & \multicolumn{1}{c}{ Country and period } \\
\hline 44 & 5.5 & Argentina 1990-97 \\
47 & 2.5 & Brazil 1990-97 \\
22 & 18.7 & Chile 1989-96 \\
33 & 4.4 & India 1990-97 \\
65 & 2.8 & Indonesia 1993-95 \\
23 & 5.0 & Israel 1993-95 \\
$>50$ &.. $\mathrm{a}$ & Italy early 1990s \\
51 & 3.9 & Korea 1991-95 \\
35 & 2.3 & Mexico 1988-97 \\
25 & 3.4 & Philippines 1992-97 \\
44 & 2.0 & Taiwan 1990-97 \\
62 & 2.3 & Thailand 1992-97 \\
52 & 1.0 & Turkey 1988-97 \\
& & \\
29 & 6.8 & Prewar Japan (largest three groups) 1932-43 \\
9 & 8.5 & Postwar Japan (Presidents' Clubs) 1977-92 \\
39 & 2 & Postwar Japan (Dodwell definition) 1977-92 \\
\hline
\end{tabular}

1 Percentage of firms affiliated with groups.

2 Median size of group-affiliated firms divided by median size of unaffiliated firms.

a Group firms are much larger.

Sources: Khanna and Yafeh (2001), except Italy, which is from Bianchi et al. (2001). 
Table 2

Group Location across Manufacturing Industries

\begin{tabular}{|c|c|c|}
\hline Country & $\begin{array}{l}\text { The groups' most important } \\
\text { industries }\end{array}$ & $\begin{array}{l}\text { Industries in which group } \\
\text { market share is largest }\end{array}$ \\
\hline Argentina & $\begin{array}{l}\text { Oil refining and natural resource } \\
\text { extraction, metals. }\end{array}$ & $\begin{array}{l}\text { Oil refining and natural } \\
\text { resource extraction, textiles, } \\
\text { metals. }\end{array}$ \\
\hline Brazil & $\begin{array}{l}\text { Chemicals, Oil refining and natural } \\
\text { resource extraction; metals. }\end{array}$ & $\begin{array}{l}\text { Food, lumber and wood, } \\
\text { metals }\end{array}$ \\
\hline Chile & $\begin{array}{l}\text { Firms spread across sectors, (lumber } \\
\text { and wood important). }\end{array}$ & $\begin{array}{l}\text { Food and tobacco, lumber and } \\
\text { wood, rubber and plastic. }\end{array}$ \\
\hline Indonesia & $\begin{array}{l}\text { Firms spread across sectors, lumber } \\
\text { and wood, construction, } \\
\text { transportation equipment important }\end{array}$ & $\begin{array}{l}\text { Construction, machinery, } \\
\text { transportation equipment }\end{array}$ \\
\hline Israel & Metals, Electronics, chemicals & Metals, Electronics, chemicals \\
\hline Korea & $\begin{array}{l}\text { Machinery, metals, transportation } \\
\text { equipment }\end{array}$ & $\begin{array}{l}\text { Oil refining and natural } \\
\text { resource extraction, } \\
\text { transportation equipment, } \\
\text { rubber, many sectors. }\end{array}$ \\
\hline Mexico & Food and tobacco, mining & $\begin{array}{l}\text { Food and tobacco, } \\
\text { construction, textile, mining. }\end{array}$ \\
\hline Philippines & $\begin{array}{l}\text { Food and tobacco, oil refining and } \\
\text { natural resource extraction. }\end{array}$ & $\begin{array}{l}\text { Food and tobacco, lumber and } \\
\text { wood. }\end{array}$ \\
\hline Taiwan & Machinery, textile, chemicals. & $\begin{array}{l}\text { Misc., oil refining and natural } \\
\text { resource extraction, lumber } \\
\text { and wood. }\end{array}$ \\
\hline Thailand & Firms spread across sectors & $\begin{array}{l}\text { Metals, oil refining and natural } \\
\text { resource extraction, chemicals. }\end{array}$ \\
\hline Turkey & Firms spread across sectors & $\begin{array}{l}\text { Construction, food and } \\
\text { tobacco, chemicals. }\end{array}$ \\
\hline Prewar Japan & Heavy Industry (Hadley, 1970) & Heavy Industry (Hadley, 1970) \\
\hline $\begin{array}{l}\text { Postwar Japan } \\
\text { (1987) }\end{array}$ & $\begin{array}{l}\text { One set policy - firms evenly spread } \\
\text { across sectors; a bit more weight in } \\
\text { chemicals, electronics and } \\
\text { transportation equipment }\end{array}$ & Metals, chemicals. \\
\hline
\end{tabular}

The sample periods, division between group and non-group firms, and sources are the same as in Table 1. 
Table 3

Risk and Return Characteristics of Corporate Groups

\begin{tabular}{ccl}
\hline & Standard & \\
ROA $^{1}$ & Deviation $^{2}$ & Country \\
$-3.9^{* *}$ & $-1.2^{* *}$ & Argentina \\
$1.5^{* *}$ & -1.0 & Brazil \\
$3.7^{*}$ & 0.3 & Chile \\
$2.1^{*}$ & $0.2^{*}$ & India \\
-0.5 & $-0.6^{*}$ & Indonesia \\
$2.4^{*}$ & -0.5 & Israel \\
-0.3 & $-0.7^{*}$ & Korea \\
2.1 & 0.5 & Mexico \\
3.3 & -0.4 & Philippines \\
-1.1 & $-0.6^{* *}$ & Taiwan \\
$-1.5^{*}$ & $-0.6^{* *}$ & Thailand \\
-1.7 & -2.9 & Turkey \\
-0.9 & -2.7 & Prewar Japan (three largest zaibatsu) \\
-0.2 & -0.1 & Postwar Japan (Presidents' Clubs) \\
-0.2 & $-0.2^{*}$ & Postwar Japan (Dodwell) \\
\hline
\end{tabular}

Data are for the year of maximal coverage for each country (for Japan, 1987 profitability, and standard deviation based on 1977-92), and excludes firms with profit rates above 100 percent or below -100 percent.

1 Difference in median ROA between group and non-group firms.

2 Difference in median of standard deviation of ROA between group and non-group firms

Significance levels for the comparisons of medians are based on Wilcoxon signed-rank tests. Significance at the $5 \%$ level is denoted by *; at the $10 \%$ level by **.

Data sources: See Khanna and Yafeh (2001). 
Table 4

Growth of Industries in Japan and the US, 1970-1995

\begin{tabular}{|l|c|c|}
\hline $\begin{array}{l}\text { Fastest growing industries } \\
\text { measured by capital } \\
\text { formation }\end{array}$ & Japan & US \\
& $\begin{array}{c}\text { Electrical machinery } \\
\text { transportation equipment } \\
\text { non-electrical machinery } \\
\text { Metals }\end{array}$ & $\begin{array}{c}\text { Plastic } \\
\text { Eon-electrical machinery } \\
\text { Chemical machinery } \\
\text { Chicals (non industrial) }\end{array}$ \\
\hline $\begin{array}{l}\text { Fastest growing industries } \\
\text { measured by growth of } \\
\text { value added }\end{array}$ & Tobacco & Electrical Machinery \\
& Plastic & "Professional Goods" \\
& Printing & Machinery \\
& Electrical machinery \\
Slowest growing industries & Chemicals (non-industrial) & Metals \\
measured by capital & Wood & Iron \\
formation & Footwear & Shipbuilding \\
& Leather & Tobacco \\
& Apparel & Footwear \\
\hline Slowest growing industries & Shipbuilding & Leather \\
measured by growth of & Iron & Wood \\
value added & Wood & Footwear \\
& Shipbuilding & Leather \\
& Textile & Apparel \\
& Furniture & Shipbuilding \\
\hline
\end{tabular}

Source: Carlin and Mayer (1999). 
Table 5

Corporate Groups, 1991-2000

\begin{tabular}{ccccl}
\hline \hline \multicolumn{3}{c}{$\begin{array}{c}\text { Group } \\
\text { firms }\end{array}$} & \multicolumn{2}{c}{ Other firms } \\
Mea & $\mathrm{SD}^{1}$ & Mea & $\mathrm{SD}^{1}$ & \\
$\mathrm{n}$ & & $\mathrm{n}$ & & \\
4150 & - & 2883 & - & Number of observations \\
$287^{*}$ & 566 & 191 & 494 & Total assets (billion yen) \\
$0.57^{*}$ & 0.17 & 0.54 & 0.26 & Debt/assets \\
$3.8^{*}$ & 3.5 & 4.0 & 4.5 & ROA $(\%)$ \\
$2.0^{*}$ & 1.2 & 2.4 & 1.5 & Standard deviation of ROA $(\%)^{3}$ \\
3.0 & 3.3 & 3.2 & 4.6 & Operating profit as \% assets \\
2.9 & 3.5 & 3.1 & 5.4 & Ordinary profit as \% assets \\
\hline
\end{tabular}

Group affiliation is based on the 1994 Keiretsu no Kenkyu definition. Note that the percentage of group-affiliated companies in this sample is somewhat higher than in earlier studies.

Statistical significance at the $5 \%$ level is denoted by *.

1 Standard deviation.

2 Total number of observations over the entire period.

3 Mean (within firm) standard deviation of ROA.

4 Ordinary profit is total profit (operating and other income, including capital gains, losses, and depreciation) after interest expenses. 
Table 6

Profitability Regressions, 1991-2000

\begin{tabular}{|c|c|c|c|c|c|c|}
\hline \multicolumn{2}{|c|}{ ROA } & \multicolumn{2}{|c|}{$\begin{array}{c}\text { Operating } \\
\text { profits/assets }\end{array}$} & \multicolumn{2}{|c|}{$\begin{array}{c}\text { Ordinary } \\
\text { profits/assets }\end{array}$} & \multirow[b]{2}{*}{ Group dummy } \\
\hline$-0.38 *$ & $(0.09)$ & $-0.30 *$ & $(0.08)$ & $-0.24 *$ & $(0.09)$ & \\
\hline$-5.75 *$ & $(0.51)$ & $-6.19 *$ & $(0.35)$ & $-10.37 *$ & $(1.48)$ & Debt/assets \\
\hline$-5.64 *$ & $(0.39)$ & $-5.35^{*}$ & $(0.40)$ & $-6.62 *$ & $(0.40)$ & $\begin{array}{l}\text { Fixed assets/total } \\
\text { assets }\end{array}$ \\
\hline $0.56^{*}$ & $(0.06)$ & $0.57 *$ & $(0.06)$ & $0.69 *$ & $(0.10)$ & Log (sales) \\
\hline$-0.14 *$ & $(0.06)$ & $-0.24 *$ & $(0.06)$ & $-0.24 *$ & $(0.07)$ & $\begin{array}{l}\text { Standard deviation of } \\
\text { ROA }\end{array}$ \\
\hline & & & & & & $\begin{array}{l}\text { Percentage of shares } \\
\text { held by: }\end{array}$ \\
\hline 0.011 & $(0.004)$ & $0.015^{*}$ & $(0.005)$ & $0.017 *$ & $(0.005)$ & Top-12 shareholders \\
\hline $0.05^{*}$ & $(0.01)$ & $0.03 *$ & $(0.01)$ & $0.02 *$ & $(0.01)$ & Individuals \\
\hline 0.004 & $(0.005)$ & 0.002 & $(0.004)$ & 0.004 & $(0.006)$ & Financial institutions \\
\hline$-0.09 *$ & $(0.03)$ & -0.06 & $(0.03)$ & -0.09 & $(0.04)$ & Non-financial firms \\
\hline 0.29 & - & 0.28 & - & 0.41 & - & $\mathrm{R}^{2}$ \\
\hline
\end{tabular}

The dependent variables are measures of profitability and the regressions are OLS using pooled data with heteroskedasticity-consistent standard errors reported in parentheses. The group affiliation dummy equals one for firms that are classified as group members using the 1994 Keiretsu no Kenkyu definition. In all three cases $\mathrm{N}$ is 7033, and year dummies and industry dummies are used.

Statistical significance at the $5 \%$ level is denoted by * 
Table 7

Trends in Cross Shareholding of Major Groups

Average percentage of shares of a member firm cross-held by other group firms. ${ }^{1}$

\begin{tabular}{|c|c|c|c|c|c|}
\hline $\begin{array}{c}198 \\
7\end{array}$ & $\begin{array}{c}199 \\
7\end{array}$ & $\begin{array}{c}200 \\
0\end{array}$ & $\begin{array}{l}\text { Change } \\
\text { '97-' } 00^{2}\end{array}$ & Group $^{3}$ & \\
\hline 14.8 & 14.0 & 11.3 & -19.3 & Mitsubishi & \\
\hline 13.4 & 11.3 & 8.9 & -21.3 & Sumitomo & \\
\hline 10.2 & 7.6 & 5.1 & -32.9 & Mitsui & \\
\hline 11.2 & 7.7 & 4.6 & -40.3 & Fuji & \\
\hline 9.1 & 7.9 & 6.2 & -21.5 & $\begin{array}{l}\text { Dai-Ichi } \\
\text { (DKB) }\end{array}$ & Kangyo \\
\hline 9.3 & 7.3 & 4.9 & -32.9 & Sanwa & \\
\hline
\end{tabular}

1 The figures refer to cross-shareholding only, as identified by NLI, as opposed to all "stable" shareholding within the group.

2 Percentage change in cross shareholding from 1997 to 2000.

3 Group firms as identified by NLI.

Source: NLI (2001), Table 5 